\title{
The Influence of Cross-Cultural Experiences \& Location on Teachers' Perceptions of Cultural Competence
}

\author{
Solange A. Lopes-Murphy ${ }^{1}$ and Christopher G. Murphy ${ }^{2}$
}

\begin{abstract}
The increasing cultural and linguistic diversity in academic settings necessitates greater cultural competence on the part of teachers, and enhancing the cultural competence of teachers requires a greater understanding of both the level of cultural competence among teachers and the experiences that enhance cultural competence. Teacher educators and pre-and in-service teachers from two geographic regions in the U.S. completed a cultural competence survey, and their responses were used to construct a cultural competence score. Cultural competence scores were higher in the Mid-Atlantic location than in the Midwest location, and the scores of participants were positively related to the extent of three cross-cultural experiences (speaking a foreign language, having been abroad, and having friends from other cultures). ANCOVA revealed an independent effect for teacher group and cross-cultural experiences, but not for location. The results of this study highlight the importance of cross-cultural experiences in the development of cultural competence and the importance to institutions of higher learning of understanding the cross-cultural experiences typical of the locations from where they draw their students.
\end{abstract}

Keywords: cross-culturalism, teacher education, PK-12 education.

\section{Introduction}

The increasing cultural and linguistic diversity among students presents a challenge for teachers in their efforts to ensure that each student meets the rigors of the academic world (DarlingHammond \& Bransford, 2005; Keengwe, 2010). Creating an inclusive learning experience for all students requires teaching practices that are sensitive to all learner profiles (Kumashiro, 2015). The expectation that all students assimilate and adjust to the American system and its values is now considered an obsolete and outdated practice (Taylor, Gillborn, \& Ladson-Billings, 2015), and today's teachers must understand their students and their cultures, develop relationships and connect with their students, and provide them with the educational experiences they need (Kumashiro, 2015). Such culturally relevant pedagogy is important to the academic success of students, as evidenced by a number of studies that have linked the implementation of culturally relevant pedagogies to increased test scores and to positive impacts on affective domains (e.g., motivation, interest, confidence) that are correlated with higher achievement (Aronson \& Laughter, 2015).

The transition from traditional classroom practices to culturally sensitive contexts that value students' diverse cultural perspectives requires teachers to be culturally competent (Skepple, 2014; Villegas \& Lucas, 2002), that is, to have the skills to "function effectively across cultures"

\footnotetext{
${ }^{1}$ Department of Special Education, Language and Literacy, The College of New Jersey, P.O. Box 7718, Ewing, NJ 08628, murphys@tcnj.edu.

2 Academic Affairs, The College of New Jersey, P.O. Box 7718, Ewing, NJ 08628, murphych@tcnj.edu.
} 
(Van Dyne, Ang, \& Livermore, 2009, p. 2). Culturally competent individuals exhibit “...openness towards other cultures, respect for different values and curiosity, knowledge of the self and the other, and awareness of cultural difference..." (Krajewski, 2011, p. 138). They have the desire and motivation to pursue opportunities for cross-cultural interactions and relationships (Ang, Van Dyne, Koh, Ng, Templer, Tay, \& Chandrasekar, 2007). They examine closely the norms, practices, and values that characterize other cultures and how those cultures compare to one another (Crowne, 2008; Van Dyne et al., 2009; Lopes-Murphyf, 2014; McCrea \& Yin, 2012). They select behaviors and approaches that are likely to generate healthy cross-cultural exchanges, plan strategies ahead of the actual cross-cultural encounter, and continuously monitor the selected behaviors during these interactions (Van Dyne et al., 2009; Molina, 2013). Finally, they are able to adjust their verbal and non-verbal behaviors appropriately in diverse cultural contexts (Crowne, 2006; Gullekson \& Tucker, 2013; Molina, 2013).

Although cultural competence and culturally responsive teaching practices have been the focus of numerous studies in the past few decades (e.g., Au \& Kawakami, 1994; Brown, 2007; Gay, 2002; Villegas \& Lucas, 2002; Wlodkowski \& Ginsberg, 1995), most teachers still lack the readiness and training necessary to create culturally inclusive classrooms (Keengwe, 2010; Molina, 2013; Skepple, 2014). Teachers still feel unprepared and uncomfortable to work with students culturally different from themselves (Aceves \& Orosco, 2014; Molina, 2013), still see their content areas and cultural diversity as incompatible areas (Skepple, 2014), and do not know much about the contributions of diverse groups to their content areas (Gay, 2002; Molina, 2013). In a time when the American culture and schools are experiencing growing diversity, teachers must have a deep enough understanding of cultural differences to be able to interact successfully with those who do not share their same cultural values and perspectives. According to Molina (2013), "there is no more room for individuals to be "culturally encapsulated"" (p. 222), especially when cultural competence is one of the key factors in helping close the achievement gap still prevalent among diverse student groups (Cazden, 2001).

To better understand the level of cultural competence among teachers, we conducted a survey to determine: 1) how teacher educators, pre-service teachers (student teachers) and inservice teachers in two locations rate their own cultural competence, 2) how cross-cultural experiences vary among teacher groups and locations, 3) whether cross-cultural experiences correlate with perceptions of cultural competence, and 4) the independent effects of teacher group, location, and cultural experience on cultural competence.

An understanding of the level of cultural competence and cross-cultural experiences among these three teacher groups is important to the preparation of culturally competent teachers, as well as college students from other disciplines. For example, if the level of cultural competence in preservice teachers is low, then teacher-education programs will need to ensure that future teachers receive training in these skills. If the same is true of in-service teachers, then both teachereducation programs and school districts may need to enhance training in cultural competence. If the cultural competence of teacher-educators is low, then cultural competence training for these individual may be needed so that they can appropriately model cultural competence and inclusivity for their students. An understanding of the relationship between cross-cultural experiences and cultural competence can provide insight into the types of experiences that might enhance cultural competence in teachers.

Journal of the Scholarship of Teaching and Learning, Vol. 16, No. 3, June 2016. josotl.indiana.edu 


\section{Methods}

\section{Participants}

The participants in the study represented three groups: teacher educators, pre-service teachers in their final field experience (student teaching), and PK-12 in-service teachers. A sample of each of the three groups was obtained from two locations, one each in the Midwest and Mid-Atlantic regions of the United States. In both locations, teacher educators and pre-service teachers were from midsized, comprehensive state institutions of higher education. In the Midwest location, inservice teachers were from a public school division serving the midsized community in which the state institution was located; Mid-Atlantic in-service teachers came from several public school divisions in communities from the same region as, but not directly adjacent to, the state institution.

A total of 195 individuals participated in the study. In the Midwest group, $29(61 \%)$ of the 47 tenure and tenure-track teacher educators responded to the survey; 20 (21.5\%) of the 93 preservice teachers responded; and $100 \%$ of the 27 PK-12 in-service teachers responded. In the MidAtlantic Group, 31 (43.7\%) of the 71 tenure and tenure-track teacher educators responded to the survey; 51 (32.7\%) of the 156 pre-service responded to the survey, and all (100\%) of the 17 PK12 in-service teachers participated in the survey. Sample sizes for individual statistical analysis were always less than 195 due to the lack of responses to some questions by some individuals.

\section{Instrument}

Participants were asked to complete a survey (Appendix A and B) that aimed to evaluate their cultural competence (Author, 2013). They responded to the 21 statements on a 5-point Likert scale ("fully agree" to "fully disagree"). Responses were coded such that the most extreme value ("fully agree" or "fully disagree") that represented the most culturally competent response was set at 5. The survey included statements similar to existing validated surveys assessing cultural competence (Hammer, 2012; Van Dyne, Ang, Ng, Rockstuhl, Tan, \& Koh, 2012), but it added statements that describe situations and experiences that college students and school teachers might encounter in their academic contexts.

Previous administrations of the survey indicated reasonable reliability $(0.77-0.80)$ for the questions on cultural competency (Lopes-Murphy, 2013). In the current study, the reliability of the overall instrument was reasonable (Cronbach's alpha $=0.78$ ) and was increased to 0.79 by omitting two questions (Appendix A). We summed the retained 19 questions to calculate a score of cultural competence. To allow comparisons with previous work and to make cultural competence scores more easily interpretable, we converted the scores to a percentage of the maximum possible score (95).

The survey also asked questions about three types of cross-cultural experiences: secondlanguage proficiency, travel or study abroad, and friendship with persons from other cultures (Appendices A and B). We chose the first two experiences because the literature indicates that these experiences are positively related to cultural competence (e.g., Crawford-Mathis, 2010; Crowne, 2008; Erwin \& Coleman 1998; Gullekson \& Tucker, 2013; MacNab, 2012; Pedersen, 2010; Salisbury, An, \& Pascarella 2013; Stebleton, Soria, \& Cherney, 2013); we chose the third experience because of the importance of cross-cultural interactions in the development of cultural competence (Van Dyne et al., 2012). The questions on foreign-language proficiency and study or travel abroad were asked in slightly different ways in two versions of the survey; hence, we used

Journal of the Scholarship of Teaching and Learning, Vol. 16, No. 3, June 2016. josotl.indiana.edu 
a scoring system that numerically aligned the responses for these two experiences between the two versions (Appendix C). We computed a cross-cultural experience score by summing the scores for the three types of experience and converting the score to a percentage of the maximum possible score (13).

\section{Survey Deployment}

All teacher educators and pre-service teachers from each institution were invited to respond to a Qualtrics survey via an email. In-service teachers received the invitation through professional development meetings in their schools, and those willing to participate in the study completed the survey either on paper $(\mathrm{N}=30)$ or via Qualtrics $(\mathrm{N}=14)$.

\section{Statistical Analyses}

All statistical procedures were carried out using IBM SPSS Statistics 21. We calculated a Spearman rank correlation to determine whether cross-cultural experiences and cultural competence scores were correlated because neither variable was normally distributed (ShapiroWilks tests, cross-cultural experience score: $W(161)=.997, \mathrm{p}=.015$; cultural competence score: $W(161)=.945, \mathrm{p}<.001)$. To determine whether cultural experience scores differed among teacher groups and locations, we made separate comparisons between locations for each teacher group, rather than conducting a two-way ANOVA because variances were not homogeneous (Levene's test, $F(5,155)=5.030, \mathrm{p}<.001)$ and transformations failed to remove heteroscedasticity. Because visual inspections of means indicated an interaction between teacher group and location, we could not conduct a non-parametric equivalent to two-way ANOVA, as rank procedures do not correctly test for interactions (Fawcett \& Salter, 1984). To maintain the family-wide Type I error rate at 05 we used the sequential Bonferroni procedure (Rice, 1989). Because all p-values remained statistically significant after application of sequential Bonferroni procedure, we present only the uncorrected p-value.

To determine the independent effects of teacher group, location, and cultural experience on cultural competence scores, we conducted a two-way ANCOVA, with teacher group as a fixed factor, location as a random factor, and the cross-cultural experience score as a covariate. The assumptions of normality of residuals (Shapiro-Wilks test, $W(161)=.991, \mathrm{p}=.40$ ), and equality of variance between compared groups (Levene's test, $F(5,155)=0.286, \mathrm{p}=.92$ ) were both met. Adding two- and three-interaction terms between the fixed factor, random factor, and covariate did not improve the fit of the model $(\mathrm{F}(2,155)=1.66$, $\mathrm{df}=7,156, \mathrm{p}=.12)$, so we fit a reduced model without interaction terms.

\section{Results}

Cultural competence scores for participants (research objective 1), expressed as a percentage of the highest possible score, were relatively high $($ mean $=78.5 \%, \mathrm{CI}=77.2-79.8 \%$, range $=53.7$ $94.7 \%$ ). Mid-Atlantic in-service teachers exhibited the highest average score of all location-teacher type combinations $(82.5 \%, \mathrm{CI}=78.5-86.5 \%)$, and Midwest pre-service teachers exhibited the lowest average $(73.0 \%, \mathrm{CI}=69.3-76.7 \%)$ (Figure 1). Cultural competence scores were higher in the Mid-Atlantic location than the Midwest (Mann-Whitney test, $U(1)=3,987, \mathrm{p}=.004$, teacher groups combined), whereas there was no significant differences among teacher groups (Kruskal-

Journal of the Scholarship of Teaching and Learning, Vol. 16, No. 3, June 2016. josotl.indiana.edu 
Wallis test, $H(2)=3.09, \mathrm{p}=.213$, locations combined).

Cross-cultural experience scores varied across locations and teacher groups (research objective 2), from an average score of $50.8 \%$ for Midwest in-service teachers to $84.4 \%$ for MidAtlantic teacher-educators (Figure 2). Average scores were greater for the Mid-Atlantic location than the Midwest location across all groups (pre-service: Mann-Whitney test, $U(1)=613.5, \mathrm{p}=$ .009 ; in-service: Mann-Whitney test, $U(1)=15.0, \mathrm{p}<.001$; teacher-educators: Mann-Whitney test, $U(1)=23.9, \mathrm{p}<.001)$. There was no significant difference among teacher groups for the Midwest location (Kruskal-Wallis test, $H(2)=3.96, \mathrm{p}=.14$ ); for the Mid-Atlantic location, the differences among teacher approached statistical significance (Kruskal-Wallis test, $H(2)=5.76$, $\mathrm{p}=.056)$.

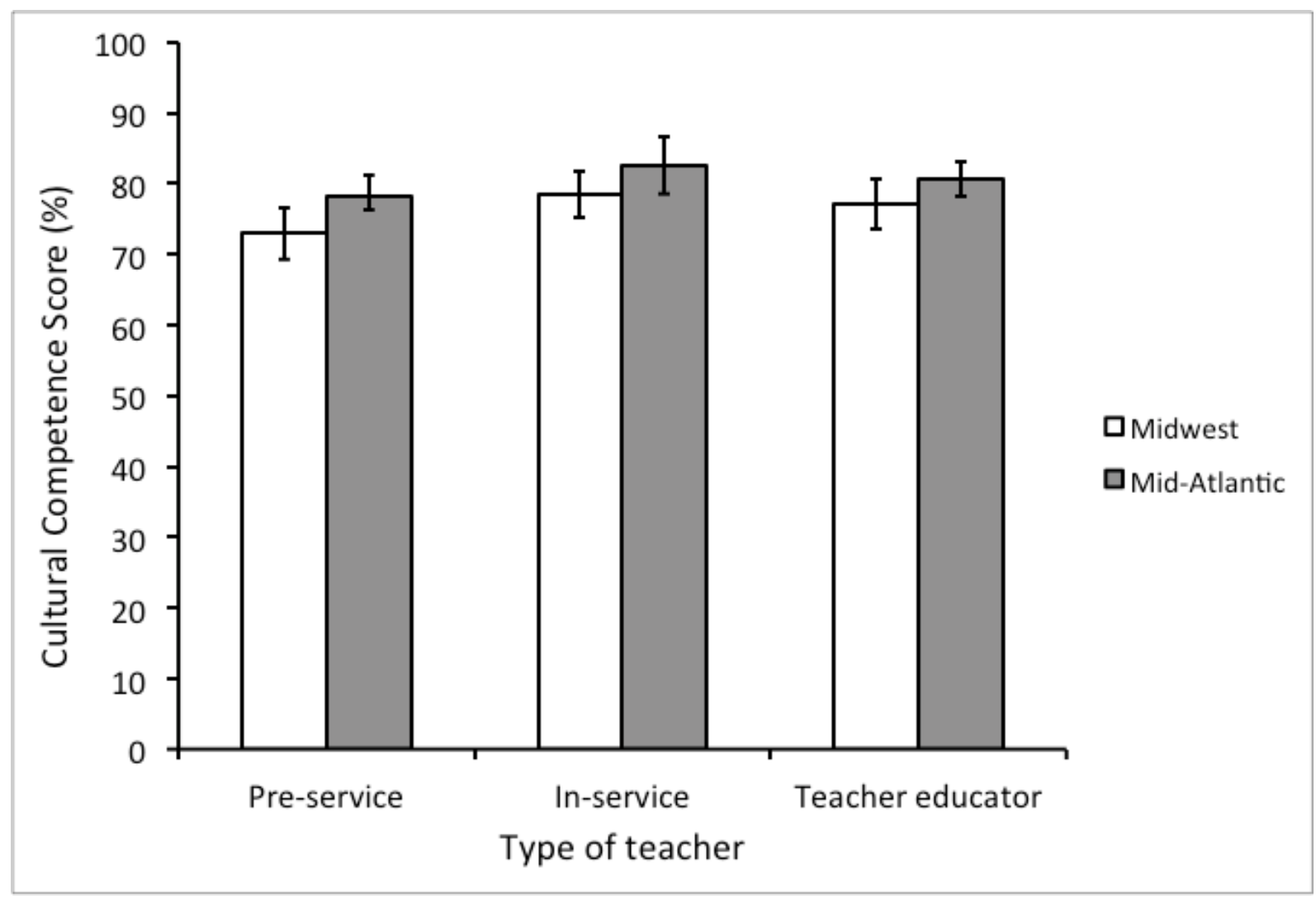

Figure 1. Mean cultural competence scores, as a percentage of the maximum possible score, for three types of teachers in two locations. Error bars represent $95 \%$ confidence intervals.

Measures of cross-cultural experiences were positively related to cultural competence scores (research objective 3). All three individual measures were positively correlated with cultural competence scores (language proficiency: $r_{s}(170)=.20, \mathrm{p}=.009$; study or travel abroad: $r_{s}(172)$ $=.25, \mathrm{p}=.009$; friends from other cultures: $\left.r_{s}(172)=.43, \mathrm{p} \leq .00001\right)$, as was the summed score of cross-cultural experiences score $\left(r_{s}(161)=.39, \mathrm{p} \leq .00001\right)$ (Figure 3$)$. Sample sizes differ among comparisons because not all participants answered all three questions about cross-cultural experiences.

Journal of the Scholarship of Teaching and Learning, Vol. 16, No. 3, June 2016.

josotl.indiana.edu 


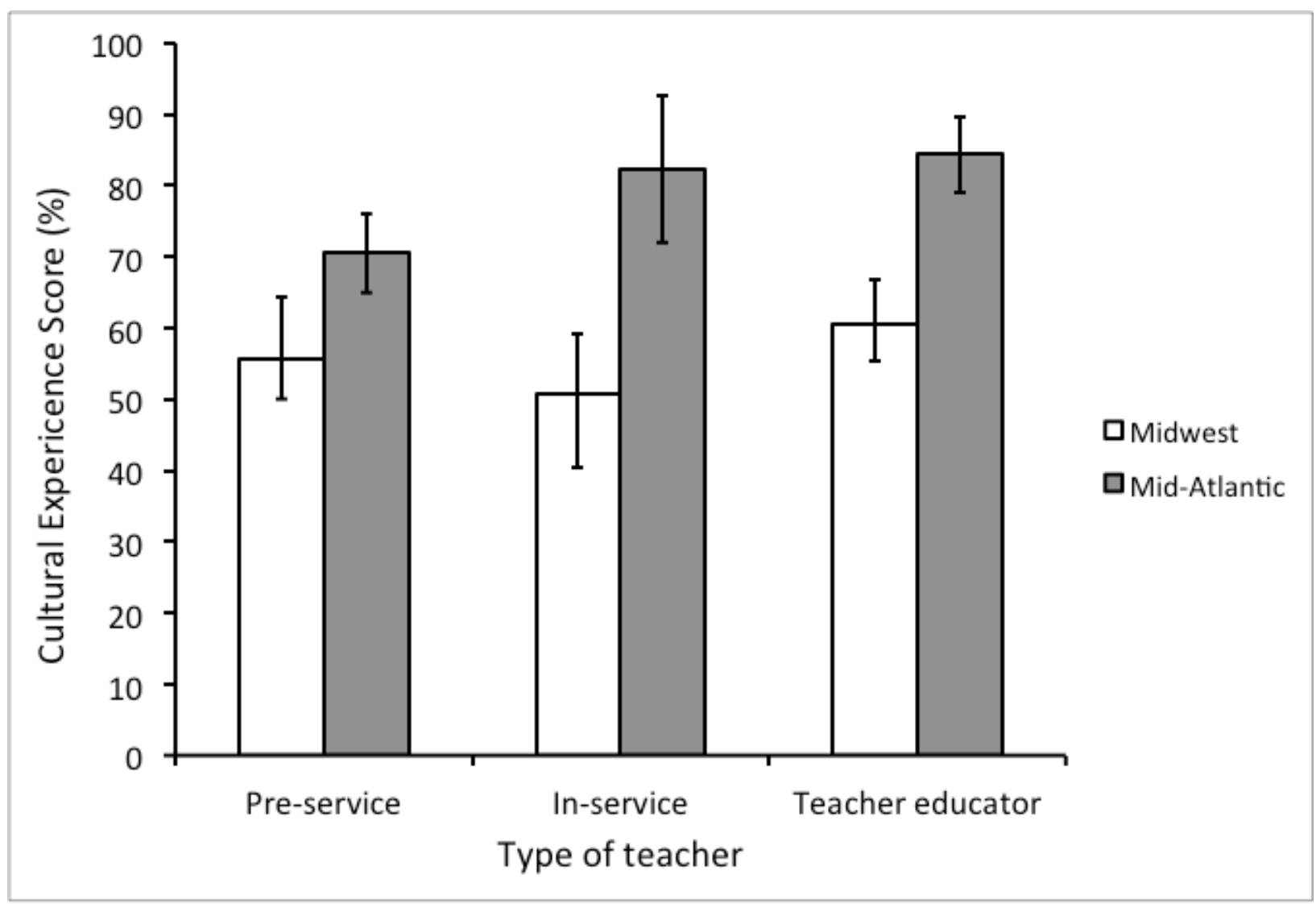

Figure 2. Average cultural experience scores, as a percentage of the maximum possible score, for three types of teachers in two locations. Error bars represent $95 \%$ confidence intervals.

Journal of the Scholarship of Teaching and Learning, Vol. 16, No. 3, June 2016.

josotl.indiana.edu 


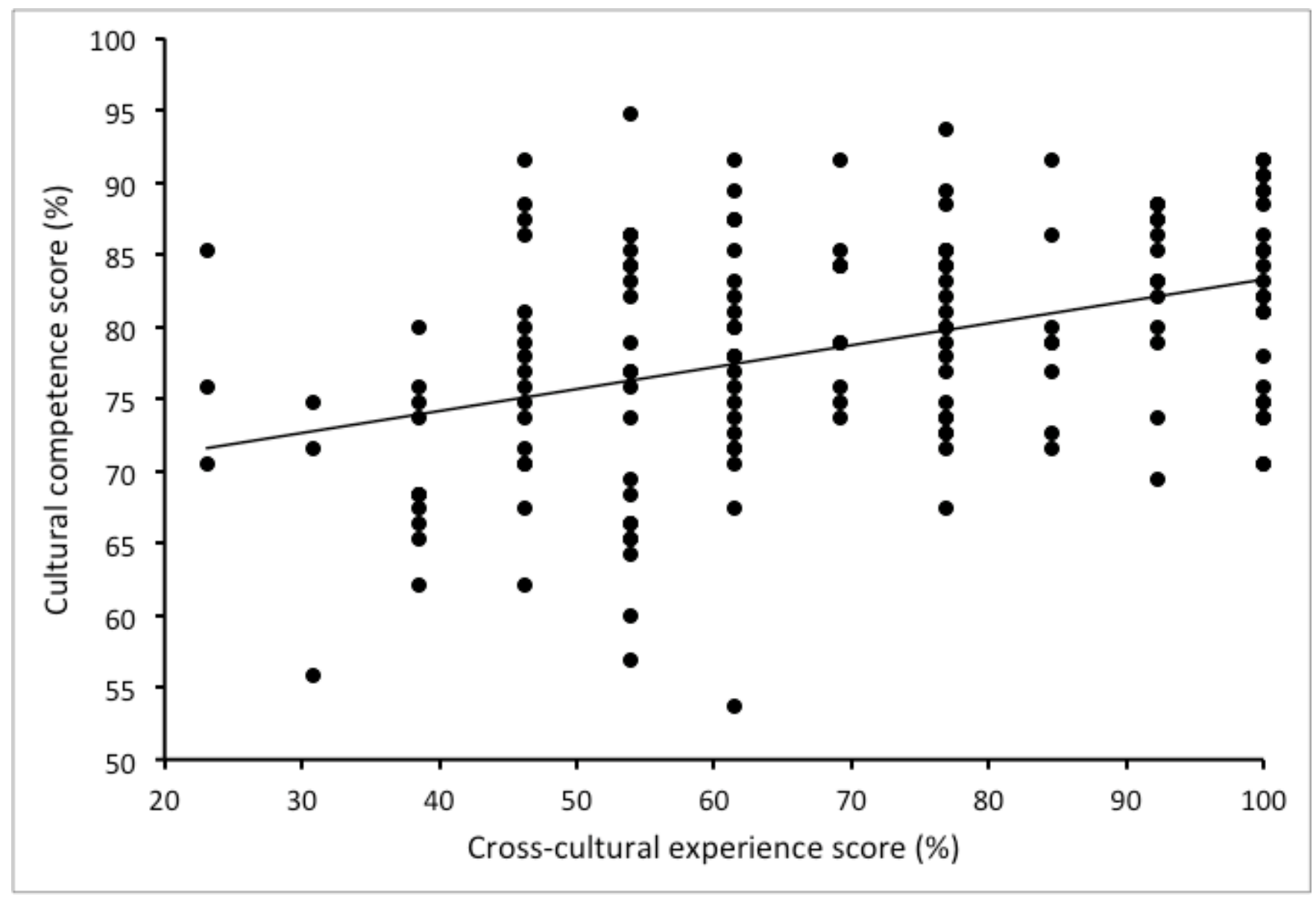

Figure 3. Cultural competence scores as a function of cross-cultural experience scores. Line represents a linear regression.

The ANCOVA to determine the independent effects of teacher group, location, and cross-cultural experiences on cultural competence (research objective 4), revealed that both teacher group $(F(2,156)=3.13 \mathrm{p}=.047)$ and cross-cultural experience $(F(1,156)=18.90, \mathrm{p}<$ $.001)$ were positively related to the cultural competence score, but location was not $(F(1,156)=$ $.75 \mathrm{p}=.38)$. Post-hoc comparisons among the three teacher groups revealed that cultural competence scores for in-service teachers were statistically significantly greater than those for preservice teachers (Bonferroni correction: $p=.017$ ) (Figure 4). All other pair-wise comparisons were not statistically significant.

Journal of the Scholarship of Teaching and Learning, Vol. 16, No. 3, June 2016.

josotl.indiana.edu 


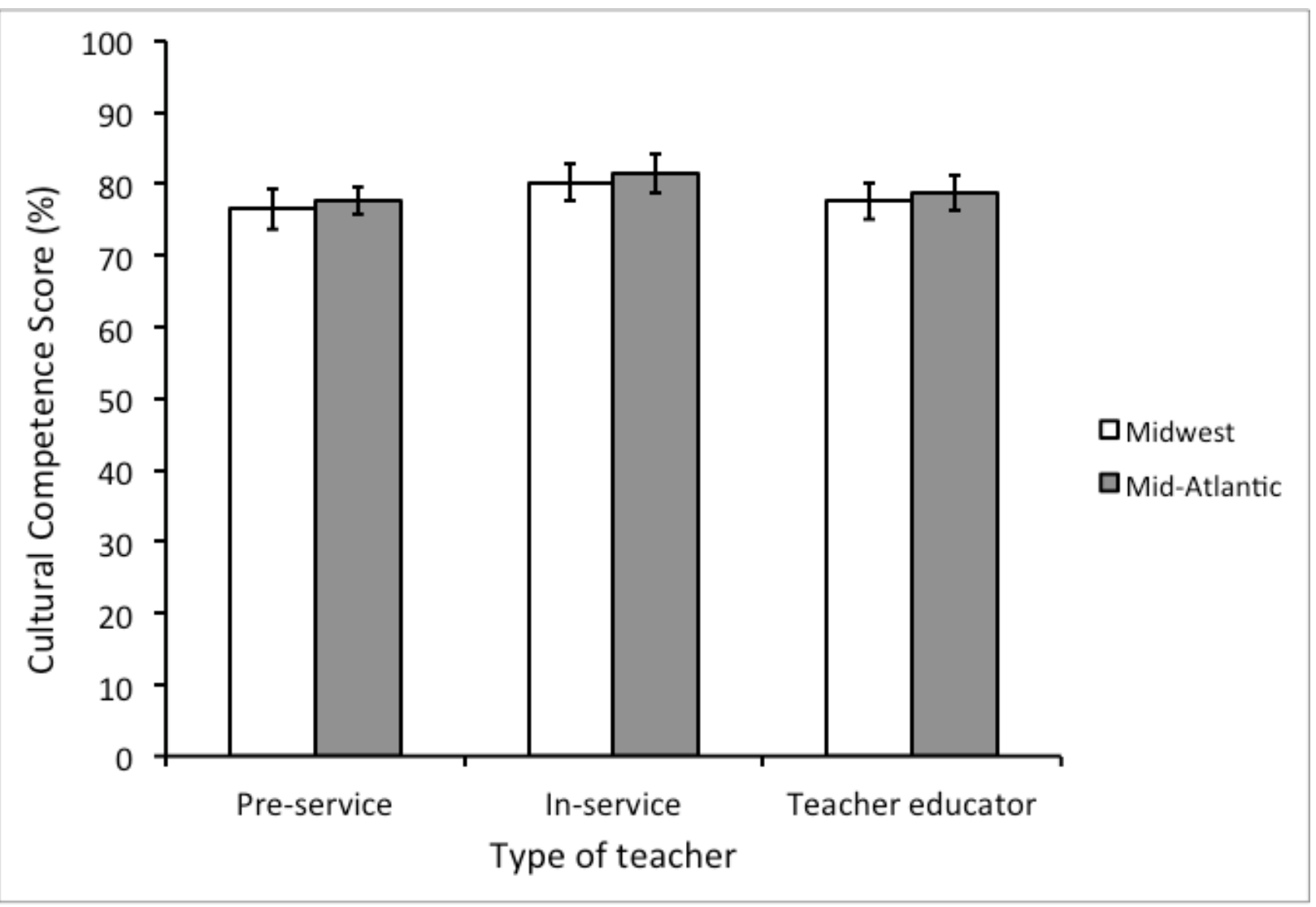

Figure 4. Mean cultural competence scores, as a percentage of the maximum possible score, for three types of teachers in two locations. Bars represent averages after adjusting for the covariate (cultural experience score), and error bars represent $95 \%$ confidence intervals.

\section{Discussion}

Our surveys revealed a positive relationship between perceptions of cultural competence and the extent of cross-cultural experiences. These results are consistent with other studies that document positive relationships between cultural competence and study or travel abroad and language proficiency (see Methods for references). Cultural competence scores were greater for the MidAtlantic than the Midwest location for each of the three teacher groups. These differences appeared to be largely due to higher cross-cultural experience scores in the Mid-Atlantic location than the Midwest location. When location and cross-cultural experience scores were both included in the statistical model along with teacher group, the cross-cultural experiences score, but not location, was statistically significantly related to the cultural competence score. These results suggest that cross-cultural experiences affect cultural competence directly, whereas the effect of location is indirect and mediated through the extent of cross-cultural experiences.

One possible explanation for the differences we observed between locations in the extent of cross-cultural experiences could be that the two locations differ in the extent to which frequent interactions with individuals from diverse cultures occur. This hypothesis is supported by an examination of the diversity within each state in which the locations reside. Racial and ethnic diversity (\% non-white, including Hispanic or Latino $=42.4 \%)$ and internationalization ( $\%$ foreign

Journal of the Scholarship of Teaching and Learning, Vol. 16, No. 3, June 2016. josotl.indiana.edu 
born $=21.2 \%)$ are greater in the state of the Mid-Atlantic location than the state of the Midwest location $(\%$ non-white $=19.3 \%$; $\%$ foreign born $=4.7 \%)$ ("Census Bureau State and County Quick Facts," 2015). Alternatively, the observed differences in cross-cultural experiences could be due to differences in the social importance placed on these experiences.

Future research could investigate these and other potential factors; knowledge of the cause of the differences in cross-cultural experience scores between the two locations could help guide public schools and teacher-training programs in the selection of effective methods for enhancing the cultural competence of future teachers. The existence of differences between locations in crosscultural experiences raises the possibility that teacher-training programs in some locations of the U.S. may need to provide more extensive training in cultural competence than other locations to offset baseline differences among locations in the extent of cross-cultural experiences that enhance cultural competence. This consideration is likely to be especially important in areas that historically have been less diverse but are currently experiencing rapid increases in diversity.

The greater perception of cultural competence by in-service teachers than by pre-service teachers that we observed is likely due to the greater opportunities that in-service teachers have to engage in activities that promote cultural competence. For example, in-service teachers are likely to have had more opportunities to accrue interactions with individuals from diverse cultures (i.e., with their students and their parents) that have in-service teachers. Examination of these opportunities would help inform teacher-training programs as to the types of experiences that would enhance the cultural competence of pre-service teachers, as well as of college students in general.

The major limitation to our study was the relatively low response rates to the surveys in some groups. The lower response rates by pre-service teachers $(22-33 \%)$ and teacher-educators $(44-61 \%)$ open the possibility that our samples of these groups were less representative than our samples of in-service teachers, whose response rate was $100 \%$.

\section{Conclusion}

Our results support the importance of cross-cultural experiences in shaping cultural competence and implicate differences among locations in the extent of these experiences as possible causes for differences among locations in levels of cultural competence. All of the points we have raised with respect to teacher-training programs are equally relevant to other groups of post-secondary students. As institutions of higher education seek to increase the cultural competence of their students, an understanding of the cross-cultural experiences that students have had, as well as those to which they will be exposed to during their college education, will be critical to maximizing gains in cultural competence.

\section{References}

Aceves, T. C., \& Orosco, M. J. (2014). Culturally responsive teaching. University of Florida, Collaboration for Effective Educator, Development, Accountability, and Reform Center. Retrieved from http://ceedar.education.ufl.edu/tools/innovation-configurations/

Ang, S., Van Dyne, L., Koh, C., Ng, K. Y., Templer, K. J., Tay, C., \& Chandrasekar, N. A. (2007). Cultural intelligence: Its measurement and effects on cultural judgment and decision making, cultural adaptation and task performance. Management and Organization Review, 3(3), 335-371.

Journal of the Scholarship of Teaching and Learning, Vol. 16, No. 3, June 2016. josotl.indiana.edu 
doi:10.1111/j.1740-8784.2007.00082.x

Aronson, B., \& Laughter, J. (2015). The theory and practice of culturally relevant education: A synthesis of research across content areas. Review of Educational Research, 1-44. DOI:

10.3102/0034654315582066

Au, K. H., \& Kawakami, A. J. (1994). Cultural congruence in instruc- tion. In E. R. Hollins, J. E. King, \& W. C. Hayman (Eds.), Teaching diverse populations: Formulating a knowledge base (pp. 5-23). Albany: State University of New York Press.

Brown, M. (2007). Educating all students: Creating culturally responsive teachers, classrooms, and schools. Intervention in School and Clinic, 43(1), 57-62.

Cazden, C. B. (2001). Classroom discourse: The language of teaching and learning ( $\left.2^{\text {nd }} \mathrm{ed}.\right)$. Portsmouth, NH: Heinemann.

Crawford-Mathis, K. (2010). Cultural intelligence and international service learning. Paper presented at the annual meeting of the Academy of Management, Montreal, Canada.

Crowne, K. A. (2008). What leads to cultural intelligence? Business Horizons, 51, 391-399. doi:10.1016/j.bushor.2008.03.010

Darling-Hammond, L., \& Bransford, J. (2005). Preparing teachers for a changing world: What teachers should learn and be able to do. New Jersey: John Wiley \& Sons.

Erwin, T. D., \& Coleman, P. K. (1998) The influence of intercultural experiences and second language proficiency on college students' cross-cultural adaptability. International Education, $28(1), 5-25$.

Fawcett, R. F. \& Salter, K. C. (1984). A Monte Carlo study of the F test and three tests based on ranks of treatment effects in randomized block designs. Communications in Statistics: Simulation and Computation, 13(2), 213-225.

Gay, G. (2002). Preparing for culturally responsive teaching. Journal of Teacher Education, 53(2), 106-116.

Gullekson, N. L., \& Tucker, M. L. (2013). An examination of the relationship between emotional intelligence and intercultural growth for students studying abroad. Journal of the Academy of Business Education, 13, 162-178.

Hammer, M.R. (2012). The Intercultural Development Inventory (IDI): A New Frontier in Assessment and Development of Intercultural Competence. In M. Vande Berg, M., Paige, R. M., \& Lou, K. (Eds.) (Ch. 5, 115-136). Student learning abroad: What our students are learning, what they're not, and what we can do about it. Sterling, VA: Stylus.

Keengwe, J. (2010). Fostering cross cultural competence in preservice teachers through

Journal of the Scholarship of Teaching and Learning, Vol. 16, No. 3, June 2016.

josotl.indiana.edu 
multicultural education experiences. Early Childhood Education Journal, 38(3), 197-204.

Krajewski, S. (2011). Developing intercultural competence in multilingual and multicultural student groups. Journal of Research in International Education, 10(2), 137-153.

Kumashiro, K. K. (2015). Against common sense: Teaching and learning toward social justice ( $3^{\text {rd }}$ ed.). New York: Routledge.

Lopes-Murphy, S. A. (2013). Evaluating the impact of two globalization projects on college students' cultural competence and cultural intelligence. Journal of Effective Teaching, 13(1), 518.

Lopes-Murphy, S. A. (2014). Experiences in postsecondary education that may lead to cultural intelligence: Exploring and proposing practices. International Journal of Teaching and Learning in Higher Education, 26(2), 287-296.

MacNab, M. R., Bennett, M. J., \& Wiseman, R. (2003). Measuring intercultural sensitivity: The intercultural development inventory. International Journal of Intercultural Relations, 27, 421-443.

McCrea, E. A., \& Yin, J. Z. (2012). Developing cultural intelligence: An undergraduate course assessment framework. Organization Management Journal, 9(2), 104-111.

doi:10.1080/15416518.2012.687992

Molina, S. C. (2013). Romanticizing culture: The role of teachers' cultural intelligence in working with diversity. The CATESOL Journal, 24(1), 220-244.

Pedersen, P. (2010). Assessing intercultural effectiveness outcomes in a year-long study abroad program. International Journal of Intercultural Relations, 34(1), 70-80.

Rice, W. R. (1989). Analyzing tables of statistical tests. Evolution 43(1), 223-225.

Salisbury, M. H., An, B. P., \& Pascarella, E. T. (2013). The effect of study abroad on intercultural competence among undergraduate college students. Journal of Student Affairs Research and Practice, 50(1), 1-20. doi:10.1515/jsarp-2013-0001

Skepple, R. G. (2014). Preparing culturally responsive pre-service teachers for culturally diverse classrooms. Kentucky Journal of Excellence in College Teaching and Learning, 12, 57-69.

Stebleton, M. J., Soria, K. M. \& Cherney, B. (2013). The high impact of education abroad: College students' engagement in international experiences and the development of intercultural competencies, Frontiers: Interdisciplinary Journal of Study Abroad, 22, 1-24.

Taylor, E., Gillborn, D., \& Ladson-Billings, G. (2015). Foundations of critical race theory in education. New York: Routledge.

United States Census Bureau. (n.d.). State and County Quick Facts. Retrieved

Journal of the Scholarship of Teaching and Learning, Vol. 16, No. 3, June 2016.

josotl.indiana.edu 
http://quickfacts.census.gov/qfd/index.html

Van Dyne, L., Ang, S., \& Livermore, D. (2009). Cultural intelligence: A pathway for leading in a rapidly globalizing world. In K. M. Hannum, B. McFeeters, \& L. Booysen (Eds.), Leadership across differences: Cases and perspectives. San Francisco, CA: Pfeiffer. Retrieved from http://linnvandyne.com/papers/Van\%20Dyne_Ang_Livermore\%20CCL\%20in\%20press.pdf

Van Dyne, L., Ang, S., Ng, K. Y., Rockstuhl, T., Tan, M. L., \& Koh, C. (2012). Sub-dimensions of the four factor model of cultural intelligence: Expanding the conceptualization and measurement of cultural intelligence. Social and Personality Psychology Compass 6(4), 295-313.

Villegas, A. M, \& Lucas, T. (2002). Preparing culturally responsive teachers: Rethinking the curriculum. Journal of Teacher Education, 53(1), 20-32.

Wlodkowski, R. J., \& Ginsberg, M. B. (1995). A framework for culturally responsive teaching. Educational Leadership, 53(1) 17-21.

\section{Appendices}

Appendix A. Survey instrument distributed to pre-service teachers and teacher educators in the Midwest location. The first four questions addressed cross-cultural experiences.

Please circle the your answer.

1. Do you speak a foreign language?

Yes

No

2. If you speak a foreign language, specify how well you speak it; otherwise, click "NonApplicable"

I just know a few words and phrases

I can understand and make myself understood.

I am proficient.

Not applicable

3. Total amount of time you have visited, lived, and/or studied in another country

Never been abroad

Less than 1 year

1-3 years

More than 3 years

4. I have friends from different cultures.

Strongly agree

Agree

Neither agree of disagree

Disagree

Strongly disagree

Journal of the Scholarship of Teaching and Learning, Vol. 16, No. 3, June 2016.

josotl.indiana.edu 


\section{Appendix A, continued.}

\begin{tabular}{|c|c|c|c|c|c|}
\hline & $\begin{array}{l}\text { Fully } \\
\text { agree }\end{array}$ & Agree & $\begin{array}{l}\text { Agree to } \\
\text { some } \\
\text { extent }\end{array}$ & Disagree & $\begin{array}{l}\text { Fully } \\
\text { disagree }\end{array}$ \\
\hline \multicolumn{6}{|l|}{ 5. People in other cultures do things the same way we do.* } \\
\hline \multicolumn{6}{|l|}{ 6. I have an interest in learning about different cultures. } \\
\hline \multicolumn{6}{|l|}{ 7. Marriage practices are different in different cultures.* } \\
\hline \multicolumn{6}{|l|}{$\begin{array}{l}\text { 8. When I meet people different from me, I compare how my } \\
\text { cultural identity is similar to theirs. }\end{array}$} \\
\hline \multicolumn{6}{|l|}{$\begin{array}{l}\text { 9. The way we do things in my culture is better than the way } \\
\text { people do things in other cultures. }\end{array}$} \\
\hline \multicolumn{6}{|l|}{$\begin{array}{l}\text { 10. What people in other cultures believe is as valuable as } \\
\text { what people in my culture believe. }\end{array}$} \\
\hline \multicolumn{6}{|l|}{$\begin{array}{l}\text { 11. The world would be better if most cultures did things the } \\
\text { same way. }\end{array}$} \\
\hline \multicolumn{6}{|l|}{$\begin{array}{l}\text { 12. I am very likely to go to an event on campus that features } \\
\text { the music, dance, and art of another culture. }\end{array}$} \\
\hline \multicolumn{6}{|l|}{$\begin{array}{l}\text { 13. Classroom activities that involve interaction with people } \\
\text { from other cultures help a person develop cultural } \\
\text { competence. }\end{array}$} \\
\hline \multicolumn{6}{|l|}{$\begin{array}{l}\text { 14. I tend to observe people different from me and reflect on } \\
\text { how they make me feel. }\end{array}$} \\
\hline \multicolumn{6}{|l|}{ 15. I think of myself as a culturally competent person. } \\
\hline \multicolumn{6}{|l|}{$\begin{array}{l}\text { 16. Being around people from other cultures makes me } \\
\text { uncomfortable. }\end{array}$} \\
\hline \multicolumn{6}{|l|}{$\begin{array}{l}\text { 17. I like to tell people from other cultures about my own } \\
\text { culture. }\end{array}$} \\
\hline \multicolumn{6}{|l|}{$\begin{array}{l}\text { 18. When I talk to a person who does speak my language well, } \\
\text { I change how I speak so they can better understand me. }\end{array}$} \\
\hline \multicolumn{6}{|l|}{$\begin{array}{l}\text { 19. People in my culture have better values than people in } \\
\text { other cultures. }\end{array}$} \\
\hline \multicolumn{6}{|l|}{ 20. I enjoy talking with people from different cultures. } \\
\hline \multicolumn{6}{|l|}{$\begin{array}{l}\text { 21. It is fair to allow students from different cultures to } \\
\text { complete assignments in different ways. }\end{array}$} \\
\hline \multicolumn{6}{|l|}{$\begin{array}{l}\text { 22. If I'm around people of other cultures, I try to behave like } \\
\text { they do. }\end{array}$} \\
\hline \multicolumn{6}{|l|}{$\begin{array}{l}\text { 23. I find it difficult to discuss subjects with people who have } \\
\text { an opinion different than I do. }\end{array}$} \\
\hline \multicolumn{6}{|l|}{ 24. I like to try foods from other cultures. } \\
\hline $\begin{array}{l}\text { 25. We learn a lot from interacting with people who are } \\
\text { different from us. }\end{array}$ & & & & & \\
\hline
\end{tabular}

*Question omitted in construction of cultural competence score.

Journal of the Scholarship of Teaching and Learning, Vol. 16, No. 3, June 2016. josotl.indiana.edu 
Appendix B. Survey Instrument distributed to all others. The first three questions of this survey addressed cross-cultural experiences.

\begin{tabular}{|c|c|c|c|c|c|}
\hline & $\begin{array}{l}\text { Fully } \\
\text { agree }\end{array}$ & Agree & $\begin{array}{l}\text { Agree to } \\
\text { some } \\
\text { extent }\end{array}$ & Disagree & $\begin{array}{l}\text { Fully } \\
\text { disagree }\end{array}$ \\
\hline 1. I speak a foreign language or a language other than English. & & & & & \\
\hline 2. I have traveled, lived, or studied abroad. & & & & & \\
\hline 3. I have friends from different cultures. & & & & & \\
\hline 4. People in other cultures do things the same way we do.* & & & & & \\
\hline 5. I have an interest in learning about different cultures. & & & & & \\
\hline 6. Marriage practices are different in different cultures.* & & & & & \\
\hline $\begin{array}{l}\text { 7. When I meet people different from me, I compare how my } \\
\text { cultural identity is similar to theirs. }\end{array}$ & & & & & \\
\hline $\begin{array}{l}\text { 8. The way we do things in my culture is better than the way } \\
\text { people do things in other cultures. }\end{array}$ & & & & & \\
\hline $\begin{array}{l}\text { 9. What people in other cultures believe is as valuable as what } \\
\text { people in my culture believe. }\end{array}$ & & & & & \\
\hline $\begin{array}{l}\text { 10. The world would be better if most cultures did things the } \\
\text { same way. }\end{array}$ & & & & & \\
\hline $\begin{array}{l}\text { 11. I am very likely to go to an event on campus that features } \\
\text { the music, dance, and art of another culture. }\end{array}$ & & & & & \\
\hline $\begin{array}{l}\text { 12. Classroom activities that involve interaction with people } \\
\text { from other cultures help a person develop cultural } \\
\text { competence. }\end{array}$ & & & & & \\
\hline $\begin{array}{l}\text { 13. I tend to observe people different from me and reflect on } \\
\text { how they make me feel. }\end{array}$ & & & & & \\
\hline 14. I think of myself as a culturally competent person. & & & & & \\
\hline $\begin{array}{l}\text { 15. Being around people from other cultures makes me } \\
\text { uncomfortable. }\end{array}$ & & & & & \\
\hline $\begin{array}{l}\text { 16. I like to tell people from other cultures about my own } \\
\text { culture. }\end{array}$ & & & & & \\
\hline $\begin{array}{l}\text { 17. When I talk to a person who does speak my language well, } \\
\text { I change how I speak so they can better understand me. }\end{array}$ & & & & & \\
\hline $\begin{array}{l}\text { 18. People in my culture have better values than people in } \\
\text { other cultures. }\end{array}$ & & & & & \\
\hline 19. I enjoy talking with people from different cultures. & & & & & \\
\hline $\begin{array}{l}\text { 20. It is fair to allow students from different cultures to } \\
\text { complete assignments in different ways. }\end{array}$ & & & & & \\
\hline $\begin{array}{l}\text { 21. If I'm around people of other cultures, I try to behave like } \\
\text { they do. }\end{array}$ & & & & & \\
\hline $\begin{array}{l}\text { 22. I find it difficult to discuss subjects with people who have } \\
\text { an opinion different than I do. }\end{array}$ & & & & & \\
\hline 23. I like to try foods from other cultures. & & & & & \\
\hline $\begin{array}{l}\text { 24. We learn a lot from interacting with people who are } \\
\text { different from us. }\end{array}$ & & & & & \\
\hline
\end{tabular}

*Question omitted in construction of cultural competence score.

Appendix C. Survey Questions on Cross Cultural Experiences and their Scoring.

Journal of the Scholarship of Teaching and Learning, Vol. 16, No. 3, June 2016. josotl.indiana.edu 


\begin{tabular}{|c|c|c|}
\hline Question & Possible Responses & $\begin{array}{l}\text { Scoring of } \\
\text { Response }\end{array}$ \\
\hline \multicolumn{3}{|c|}{ Pre-Service Teachers and Teacher Educators in the Midwest Location } \\
\hline $\begin{array}{l}\text { Do you speak a foreign } \\
\text { language? }\end{array}$ & Yes, No & Not scored \\
\hline $\begin{array}{l}\text { If you speak a foreign } \\
\text { language, specify how well } \\
\text { you speak it; otherwise, } \\
\text { click "Non-Applicable" }\end{array}$ & $\begin{array}{l}\text { I just know a few words and phrases } \\
\text { I can understand and make myself understood. } \\
\text { I am proficient. } \\
\text { Not applicable }\end{array}$ & $\begin{array}{l}1 \\
2 \\
3 \\
4\end{array}$ \\
\hline $\begin{array}{l}\text { Total amount of time you } \\
\text { have visited, lived, and/or } \\
\text { studied in another country }\end{array}$ & $\begin{array}{l}\text { Never been abroad } \\
\text { Less than } 1 \text { year } \\
1-3 \text { years } \\
\text { More than } 3 \text { years }\end{array}$ & $\begin{array}{l}1 \\
2 \\
3 \\
4\end{array}$ \\
\hline $\begin{array}{l}\text { I have friends from } \\
\text { different cultures. }\end{array}$ & $\begin{array}{l}\text { Strongly agree } \\
\text { Agree } \\
\text { Neither agree of disagree } \\
\text { Disagree } \\
\text { Strongly disagree }\end{array}$ & $\begin{array}{l}5 \\
4 \\
3 \\
2 \\
1\end{array}$ \\
\hline \multicolumn{3}{|l|}{ All others } \\
\hline $\begin{array}{l}\text { I speak a foreign language } \\
\text { or a language other than } \\
\text { English. }\end{array}$ & $\begin{array}{l}\text { Strongly agree } \\
\text { Agree } \\
\text { Neither agree of disagree } \\
\text { Disagree } \\
\text { Strongly disagree }\end{array}$ & $\begin{array}{l}4 \\
3.25 \\
2.5 \\
1.75 \\
1\end{array}$ \\
\hline $\begin{array}{l}\text { I have traveled, lived, or } \\
\text { studied abroad. }\end{array}$ & $\begin{array}{l}\text { Strongly agree } \\
\text { Agree } \\
\text { Neither agree of disagree } \\
\text { Disagree } \\
\text { Strongly disagree }\end{array}$ & $\begin{array}{l}4 \\
3.25 \\
2.5 \\
1.75 \\
1\end{array}$ \\
\hline $\begin{array}{l}\text { I have friends from } \\
\text { different cultures. }\end{array}$ & $\begin{array}{l}\text { Strongly agree } \\
\text { Agree } \\
\text { Neither agree of disagree } \\
\text { Disagree } \\
\text { Strongly disagree }\end{array}$ & $\begin{array}{l}5 \\
4 \\
3 \\
2 \\
1\end{array}$ \\
\hline
\end{tabular}

Journal of the Scholarship of Teaching and Learning, Vol. 16, No. 3, June 2016. josotl.indiana.edu 